\title{
Pengaruh Suplementasi Ekstrak Daun Katuk (Sauropus androgynus) dan Tepung Kunyit (Curcuma domestica) terhadap Kualitas Karkas pada Broiler yang Diberi Pakan Berprotein Rendah
}

\author{
Effect of Supplementation of Katuk Leaf Extract (Sauropus androgynus) and Turmeric Flour \\ (Curcuma domestica) on Carcass Quality in Broilers Feeded with Low Protein \\ B. Nurkhasanah ${ }^{*}$, Kususiyah $^{* *}$ dan U. Santoso ${ }^{* *}$ \\ "Mahasiswa Peternakan, Fakultas Pertanian Universitas Bengkulu \\ ** Dosen Jurusan Peternakan, Fakultas Pertanian Universitas Bengkulu \\ Jalan W.R Supratman Kandang Limun Bengkulu 38371A \\ Corresponding author: santoso@unib.ac.id
}

\begin{abstract}
This study aimed to evaluate the effect of supplementation of Sauropus androgynus leaf extract (SALE) and turmeric (Curcuma domestica) powder (TP) on carcass quality in broilers fed low-protein diet. It was hypothesized that supplementation of SALE plus TP improved carcass quality in broilers fed low-protein diets. Sixty broiler chickens aged 14 days were distributed into 5 groups with 4 replications. Each replications contained three broiler chickens. One group was fed $19 \%$ protein diet without supplementation (P0), and other groups were fed $17 \%$ protein diet with $4.5 \mathrm{~g}$ SALE/ $\mathrm{kg}$ plus $0.5 \% \mathrm{TP}(\mathrm{P} 1), 17 \%$ protein diet with $4.5 \mathrm{~g}$ SALE/ $\mathrm{kg}$ plus $1 \% \mathrm{TP}(\mathrm{P} 2), 15 \%$ protein with $4.5 \mathrm{~g} \mathrm{SALE} / \mathrm{kg}$ plus $0.5 \% \mathrm{TP}(\mathrm{P} 3), 15 \%$ protein with $4.5 \mathrm{~g}$ SALE/ $\mathrm{kg}$ plus $1 \%$ TP (P4). with $15 \%$ protein). The experimental results showed that supplementation of SALE plus TP significantly affected carcass percentage $(\mathrm{P}<0.01)$, meat bone ratio $(\mathrm{P}<0.05)$ and drip loss, whereas the treatments had no effect on $(\mathrm{P}>0.05)$ cooking loss. SALE plus TP inclusion improved the color of carcass. It could be concluded that supplementation of SALE plus TP improved carcass quality in broilers fed low-protein diet.
\end{abstract}

Key words: Sauropus androgynus leaf extract, curcumin powder, carcass quality, low protein diet, broiler

\begin{abstract}
ABSTRAK
Penelitian ini bertujuan untuk mengevaluasi pengaruh suplementasi ekstrak daun katuk (Sauropus androgynus) dan tepung kunyit (Curcuma domestica) terhadap kualitas karkas pada broiler yang diberi pakan berprotein rendah. Hipotesis penelitian ini bahwa suplementasi ekstrak daun katuk (Sauropus androgynus) dan tepung kunyit (Curcuma domestica) diduga dapat meningkatkan kualitas karkas pada broiler yang diberi pakan berprotein rendah. Enam puluh (60) ekor ayam broiler umur 14 hari dikelompokkan menjadi 5 kelompok perlakuan dengan 4 ulangan. Masing-masing ulangan berisi 3 ekor broiler. Perlakuan yang digunakan adalah P0 (protein 19\% tanpa EDK dan TK), P1 (4,5 g/kg EDK plus 0,5\% TK dengan protein 17\%), P2 (4,5 g/kg EDK plus $1 \%$ TK dengan protein $17 \%), \mathrm{P} 3$ (4,5 g/kg EDK plus 0,5\% TK dengan protein 15\%), P2 (4,5 g/kg EDK plus $1 \%$ TK dengan protein 15\%). Hasil penelitian menunjukkan bahwa suplementasi EDK dan TK berpengaruh sangat nyata $(\mathrm{P}<0,01)$ terhadap persentase karkas, meat bone ratio $(\mathrm{P}<0,05)$ dan drip loss, tetapi berpengaruh tidak nyata $(\mathrm{P}>0,05)$ terhadap susut masak. Perlakuan meningkatkan warna karkas. Dapat disimpulkan bahwa suplementasi EDK plus TK meningkatkan kualitas karkas pada broiler yang diberi pakan berprotein rendah.
\end{abstract}

Kata kunci : Ekstrak daun katuk, tepung kunyit, kualitas karkas, protein rendah, broiler.

\section{PENDAHULUAN}

Pakan sangat dibutuhkan sebagai penunjang kebutuhan hidup ternak. Ahli nutrisi unggas akhir-akhir ini banyak tertarik untuk menurunkan kadar protein dalam pakan broiler. Ada beberapa alasan, yaitu: 1) pemberian pakan berprotein rendah akan menurunkan biaya pakan karena protein merupakan zat nutrisi yang termahal dalam pakan broiler; 
pemberian pakan berprotein rendah akan menurunkan tingkat pencemaran akibat ekskresi nitrogen yang berlebihan (ELHakim et al., 2009). Namun pemberian protein rendah dalam pakan dapat menimbulkan beberapa kerugian yaitu menurunkan performa hasil karkas (Bregendahl et al., 2002). Swennen et al. (2007) menemukan bahwa pemberian pakan berprotein rendah menurunkan retensi protein pada broiler.

Pemberian pakan berprotein rendah meningkatkan deposisi lemak pada berbagai bagian tubuh broiler dan meningkatkan kadar lemak dalam daging dan karkas (Pesti, 2009). Peningkatan deposisi lemak ini dapat menyebabkan substrat untuk sintesis protein menurun sehingga kadar protein dalam daging pun menurun. Menurunnya kadar protein dalam tubuh broiler akan berpengaruh pada meningkatnya cooking loss dan menurunnya daya mengikat air (DMA). Diduga bahwa pakan berprotein rendah menurunkan ketersediaan zat-zat gizi dalam karkas dan daging broiler sehingga menurunkan meat bone ratio dan persentase karkas. Penurunan lemak oleh ekstrak daun katuk menunjukkan ekstrak daun katuk diduga dapat meningkatkan kualitas karkas (Santoso et al., 2005, 2013)

Pemberian pakan berprotein rendah pada broiler perlu diimbangi oleh bahan pakan lain untuk menghambat penurunan kualitas karkas. Katuk (Sauropus androgynus) merupakan tanaman obatobatan tradisional yang mempunyai zat gizi tinggi, senyawa antibakteri, antioksidan dan mengandung $\beta$-karoten yang tinggi sebagai zat aktif warna karkas dan meningkatkan kadar vitamin A dalam karkas broiler. Daun menagnadung $\beta$ carotene yang tinggi (Santoso et al., 2015) Tingginya kadar $\beta$-karoten dalam daun katuk akan memberikan kontribusi terhadap peningkatan warna karkas. Santoso et al. (2001) menemukan bahwa pemberian ekstrak daun katuk (EDK) sebanyak 4,5g/l air minum meningkatkan warna kuning karkas. Santoso et al. (2002) menemukan pemberian 4,5g $\mathrm{EDK} / \mathrm{kg}$ ransum melalui kombinasi cara pemberian dapat meningkatkan warna karkas.

Daun katuk kaya akan asam glutamat dan metilpiroglutamat. Suplementasi glutamat menghasilkan peningkatan persentase hasil karkas ayam broiler (Pelicia et al., 2011). Glutamat berperan dalam interkonversi antara asam amino dan siklus asam sitrat melalui transmisi pada gluconeogenesis (Pelicia et al., 2011). Ekstraksi daun katuk menghasilkan kualitas karkas yang baik (Santoso, 2001).

Untuk lebih mengoptimalkan kualitas ayam broiler perlu ditambahkan feed additive lain. Feed additive alami yang berpotensi adalah kunyit (Curcuma domestica). Kunyit memiliki kandungan senyawa bioaktif yaitu kurkumin dan minyak atsiri (Rukmana, 2005). Zat kurkuminoid yang terkandung dalam tepung kunyit dapat meningkatkan aktifitas saluran pencernaan dan metabolisme gizi sehingga akan meningkatkan persentase karkas. Pemberian tepung kunyit meningkatkan berat relatif pada daging dada dan daging paha ayam (Durrani et al., 2006). Berdasarkan uraian diatas, maka 
suplementasi EDK dan TK diduga dapat meningkatkan kualitas karkas.

\section{MATERI DAN METODE}

\section{Ekstraksi daun katuk}

Daun katuk segar dikeringanginkan, digiling dan disimpan dalam kantong plastik. Ekstraksi dilakukan dengan merebus daun katuk pada suhu $90^{\circ} \mathrm{C}$ selama 20 menit. Ekstrak yang diperoleh dikeringkan pada suhu $55^{\circ} \mathrm{C}$ sampai berbentuk pasta.

\section{Pakan percobaan}

Anak ayam umur satu hari ditempatkan pada kandang indukan dan diperlakukan sesuai dengan standar pemeliharaan (Santoso, 2002 $\left.2^{\mathrm{a}, \mathrm{b}}\right)$. Pada umur 14 hari, 60 ekor broiler diseleksi dan di bagi menjadi 5 perlakuan dengan 4 ulangan yang ditempatkan pada kandang kelompok. Perlakuan terdiri dari P0 : Pakan berprotein 19\% tanpa disuplementasi EDK dan TK, P1 : Pakan berprotein $17 \%$ disuplementasi $4,5 \mathrm{~g}$ $\mathrm{EDK} / \mathrm{kg}+0,5 \% \mathrm{TK}, \mathrm{P} 2:$ Pakan berprotein $17 \%$ disuplementasi $4,5 \mathrm{~g} \mathrm{EDK} / \mathrm{kg}+1 \%$ TK, P3 : Pakan berprotein 15\% disuplementasi 4,5 g EDK/kg + 0,5\% TK, P4 : Pakan berprotein $15 \%$ disuplementasi $4,5 \mathrm{~g} \mathrm{EDK} / \mathrm{kg}+1 \% \mathrm{TK}$. Rancangan yang digunakan pada penelitian ini adalah Rancangan Acak Lengkap (RAL). Pakan dan air minum diberikan ad libitum.

Tabel 1. Komposisi bahan pakan serta kandungan nutrisi pakan perlakuan

\begin{tabular}{llllll}
\hline & \multicolumn{3}{l}{ Perlakuan } & & \\
\cline { 2 - 6 } Bahan pakan & P0 & P1 & P2 & P3 & P4 \\
\hline Jagung giling (\%) & 57 & 60,69 & 60,69 & 59,44 & 59,44 \\
Dedak (\%) & 5 & 8,37 & 7,87 & 17,12 & 16,62 \\
Konsentrat broiler(\%) & 34,2 & 26,69 & 26,69 & 19,19 & 19,19 \\
Mineral mix (\%) & 1,7 & 1,7 & 1,7 & 1,7 & 1,7 \\
Garam dapur(\%) & 0,1 & 0,1 & 0,1 & 0,1 & 0,1 \\
Top mix (\%) & 0,5 & 0 & 0 & 0 & 0 \\
Minyak (\%) & 1,5 & 1,5 & 1,5 & 1,5 & 1,5 \\
Ekstrak katuk (\%) & 0 & 0,45 & 0,45 & 0,45 & 0,45 \\
Tepung kunyit (\%) & 0 & 0,5 & 1 & 0,5 & 1 \\
Total (gram) & 100 & 100 & 100 & 100 & 100 \\
Kandungan Nutrisi : & & & & & \\
PK & 19,17 & 17,10 & 17,10 & 15,12 & 15,12 \\
ME (kkal/kg) & 3198,11 & 3233,65 & 3234,98 & 3230,90 & 3232,23 \\
Kalsium (\%) & 1,51 & 1,31 & 1,31 & 1,11 & 1,11 \\
Phospor (\%) & 0,73 & 0,69 & 0,69 & 0,71 & 0,71 \\
\hline
\end{tabular}


Sampling

Pada akhir penelitian 4 ekor broiler (umur 35 hari) pada setiap perlakuaan diseleksi dan dipotong. Variabel yang diukur adalah persentase berat karkas, meat bone ratio, warna karkas, cooking loss dan drip loss. Persentase karkas diukur dengan membagi berat karkas dengan berat hidup dikalikan $100 \%$.
Warna karkas diukur dengan membandingkan warna kulit dada dengan warna standard menurut DSM broiler fan. Meat bone ratio diukur dengan membagi berat daging dada dan paha dengan berat tulang dada dan paha. Cooking loss diukur dengan merebus daging bagian dada pada suhu $80^{\circ} \mathrm{C}$ selama 20 menit. Cooking loss dihitung dengan formula sebagai berikut.

Cooking loss $(\%)=$ Berat daging sebelum direbus - berat daging setelah direbus $\times 100 \%$

Berat daging sebelum direbus

Drip loss dilakukan dengan cara menyimpan daging dalam freezer selama 72 jam. Drip loss dihitung dengan rumus sebagai berikut.

Drip loss $(\%)=$ Berat daging sebelum dibekukan - berat daging setelah dithawing $\times 100 \%$ Berat daging sebelum dibekukan

Analisis data

Data hasil penelitian dianalisis keragamannya, jika hasil analisis berpengaruh nyata $(\mathrm{P}<0,05)$ maka dilakukan uji lanjut dengan Duncan's Multiple Range Test. Warna karkas dianalisis secara deskriptif.

\section{HASIL DAN PEMBAHASAN}

Pengaruh suplementasi ekstrak daun katuk (EDK) dan tepung kunyit (TK) terhadap persentase karkas, meat bone ratio (MBR), warna karkas, susut masak dan drip loss disajikan pada Tabel 2.

Tabel 2. Rataan persentase karkas, MBR, warna karkas, susut masak dan drip loss

\begin{tabular}{lcccccl}
\hline \multirow{2}{*}{ Variabel } & \multicolumn{5}{c}{ Perlakuan } & \multirow{2}{*}{$\mathrm{P}$} \\
\cline { 2 - 6 } & $\mathrm{P} 0$ & $\mathrm{P} 1$ & $\mathrm{P} 2$ & $\mathrm{P} 3$ & $\mathrm{P} 4$ & \\
\hline Persentase karkas & $69,70 \pm 1,17^{\mathrm{a}}$ & $67,20 \pm 0,22^{\mathrm{b}}$ & $66,82 \pm 0,33^{\mathrm{b}}$ & $63,93 \pm 0,79^{\mathrm{c}}$ & $63,37 \pm 0,64^{\mathrm{c}}$ & 0,000 \\
Meat bone ratio & $4,20 \pm 0,44^{\mathrm{a}}$ & $3,53 \pm 0,67^{\mathrm{ab}}$ & $2,80 \pm 0,59^{\mathrm{b}}$ & $3,18 \pm 0,35^{\mathrm{b}}$ & $2,98 \pm 0,51^{\mathrm{b}}$ & 0,01 \\
Warna karkas & $102,0 \pm 0,71$ & $102,25 \pm 0,5$ & $103 \pm 0,41$ & $102,75 \pm 0,87$ & $102,38 \pm 0,48$ & \\
Susut masak & $19,20 \pm 0,42^{\mathrm{a}}$ & $19,45 \pm 0,57^{\mathrm{a}}$ & $20,65 \pm 1,69^{\mathrm{a}}$ & $21,05 \pm 0,90^{\mathrm{a}}$ & $19,85 \pm 3,95^{\mathrm{a}}$ & 0,65 \\
Drip loss & $12,81 \pm 0,48^{\mathrm{a}}$ & $5,72 \pm 0,49^{\mathrm{b}}$ & $5,42 \pm 1,27^{\mathrm{b}}$ & $5,22 \pm 0,85^{\mathrm{b}}$ & $12,20 \pm 0,39^{\mathrm{a}}$ & 0,00 \\
\hline
\end{tabular}

Superskrip yang berbeda pada baris yang sama menunjukkan berbeda sangat nyata $(\mathrm{P}<0,01)$ atau berbeda nyata $(\mathrm{P}<0,05)$. $\mathrm{P} 0=$ Pakan berprotein $19 \%$ tanpa disuplementasi esktark daun katuk (EDK) dan tepung kunyit (TK); $\mathrm{P} 1=$ Pakan berprotein 17\% disuplementasi 4,5 g EDK $/ \mathrm{kg}+0,5 \% \mathrm{TK} ; \mathrm{P} 2=$ Pakan berprotein 17\% disuplementasi 4,5 g $\mathrm{EDK} / \mathrm{kg}+1 \% \mathrm{TK} ; \mathrm{P} 3=$ Pakan berprotein $15 \%$ disuplementasi $4,5 \mathrm{~g}$ EDK $/ \mathrm{kg}+0,5 \% \mathrm{TK} ; \mathrm{P} 4=$ Pakan berprotein $15 \%$ disuplementasi $4,5 \mathrm{~g}$ EDK $/ \mathrm{kg}+1 \% \mathrm{TK}$. 


\section{Persentase Karkas}

Hasil analisis ragam menunjukkan bahwa suplementasi EDK dan TK berpengaruh sangat nyata $(\mathrm{P}<0,01)$ terhadap persentase karkas ayam broiler. Hasil uji lanjut menunjukkan bahwa persentase karkas pada broiler yang diberi pakan protein rendah yang disuplementasi EDK dan TK (P1, P2, P3 dan P4) nyata lebih rendah $(\mathrm{P}<0,05)$ dibanding dengan kontrol (P0). Persentase karkas pada P1 dan P2 (protein 17\%) berbeda sangat nyata $(\mathrm{P}<0,01)$ lebih tinggi dibandingkan dengan P3 dan P4 (protein 15\%).

Hasil penelitian ini menunjukkan bahwa suplementasi EDK 4,5g/kg dan TK sampai dengan $1 \%$ tidak mampu menghambat penurunan persentase karkas broiler yang diberi pakan berprotein rendah. Hasil ini sesuai dengan Bregendahl et al. (2002) bahwa pemberian pakan berprotein rendah dapat menurunkan hasil karkas. Hasil persentase karkas penelitian ini masih berada dalam nilai standar persentase karkas menurut Soeparno (2009) yaitu 65\%-75\%.

Persentase karkas yang tinggi disebabkan karena berat hidup yang relatif tinggi. Persentase karkas merupakan faktor terpenting untuk menilai produksi ternak, karena produksi erat hubungannya dengan bobot hidup. Semakin bertambah bobot hidupnya, maka produksi karkasnya akan semakin meningkat.

Konsumsi protein dari P0 sampai P4 secara berurutan adalah 509,6 gram, 435,8 gram, 443,5 gram, 374,3 gram, 389,1 gram. Lebih rendahnya konsumsi protein pada broiler yang diberi pakan berprotein rendah merupakan salah satu faktor penyebab turunnya persentase karkas. Hasil penelitian menunjukkan suplementasi EDK 4,5g/kg dan TK sampai dengan $1 \%$ pada pakan berprotein rendah menurunkan persentase karkas broiler.

\section{Meat Bone Ratio (MBR)}

Analisis ragam menunjukkan bahwa suplementasi EDK dan TK berpengaruh nyata $(\mathrm{P}<0,05)$ terhadap MBR. Hasil uji lanjut menunjukkan bahwa MBR P0 berbeda tidak nyata $(\mathrm{P}>0,05)$ dengan $\mathrm{P} 1$, tetapi nyata lebih tinggi dibanding P2, P3 dan P4.

Hal ini menunjukkan bahwa suplementasi EDK dan TK pada pakan berprotein rendah tidak mampu mencegah penurunan MBR. Turunnya MBR dengan pakan berprotein rendah diduga disebabkan rendahnya konsumsi protein. Rendahnya konsumsi protein akan berpengaruh terhadap pertumbuhan jaringan dan pertumbuhan jaringan yang terhambat akan berpengaruh terhadap pembentukan daging. Hal ini dapat menyebabkan perbandingan daging dengan tulang lebih kecil. Santoso et al. (2001) melaporkan bahwa suplementasi EDK dengan berbagai cara pemberian berpengaruh tidak nyata terhadap perbandingan daging dan tulang pada broiler yang diberi pakan berprotein normal. Hasil penelitian menunjukkan suplementasi EDK 4,5g/kg dan TK sampai $1 \%$ pada pakan berprotein rendah tidak mampu mencegah penurunan MBR. 


\section{Warna Karkas}

Warna karkas dibahas secara deskripif. Warna karkas P1, P2, P3 dan P4 yang disuplementasi EDK dan TK lebih tinggi dibandingkan kontrol (P0). Menurut Santoso et al. (2015) ß-carotene yang tinggi dalam daun katuk akan memberikan kontribusi terhadap peningkatan warna karkas. Santoso (2001) menyatakan bahwa katuk adalah tanaman obat yang kaya akan $\beta$-carotene. Diperkuat kembali oleh pernyataan Santoso, (2014) pemberian EDK mampu meningkatkan warna kuning pada kaki dan karkas ayam broiler, sebab EDK kaya akan $\beta$-carotene.

Warna karkas yang lebih menarik lebih diminati karena warna merupakan faktor yang paling utama untuk dipertimbangkan dalam menentukan mutu suatu bahan makanan sebelum faktorfaktor lain (rasa) (Winarno,1994). Hasil penelitian menunjukkan suplementasi EDK $4,5 \mathrm{~g} / \mathrm{kg}$ dan TK sampai $1 \%$ pada pakan berprotein rendah dapat memperbaiki warna karkas broiler.

\section{Susut Masak}

Hasil analisis ragam menunjukkan bahwa suplementasi EDK dan TK berpengaruh tidak nyata $(\mathrm{P}>0,05)$ terhadap susut masak. Hal ini menunjukkan bahwa suplementasi EDK dan TK pada pakan berprotein rendah tidak berdampak negatif terhadap susut masak.

Rata-rata susut masak ayam broiler dalam penelitian ini sebesar 19,20\%20,65\%. Hal ini lebih rendah dibandingkan dengan pendapat Soeparno (2009) bahwa umumnya susut masak antara 30,32\%-43,48\%. Susut masak dapat dipengaruhi oleh $\mathrm{pH}$, panjang sarkomer serabut otot, panjang potongan serabut otot, status kontraksi myofibril, ukuran dan berat sampel daging dan penampang lintang daging. Santoso et al. (2002) menemukan bahwa cara pemberian ekstrak daun katuk memberikan perbedaan yang tidak nyata $(\mathrm{P}>0,05)$ terhadap susut masak. Suplementasi 4,5 g/kg dan $9 \mathrm{~g} / \mathrm{kg}$ EDK pada berbagai level protein juga berpengaruh tidak nyata terhadap susut masak (Qotimah et al., 2014). Hasil penelitian menunjukkan suplementasi EDK $4,5 \mathrm{~g} / \mathrm{kg}$ dan TK sampai $1 \%$ pada pakan berprotein rendah tidak menurunkan susut masak.

\section{Drip Loss}

Merupakan hilangnya nutrisi daging yang ikut bersama keluarnya cairan daging selama proses thawing. Cairan yang keluar dan tidak terserap kembali oleh serabut selama penyegaran disebut drip (Soeparno, 2009). Hasil analisis ragam menunjukkan bahwa suplementasi EDK dan TK berpengaruh nyata $(\mathrm{P}<0,05)$ terhadap drip loss. Hasil uji lanjut menunjukkan bahwa drip loss $\mathrm{P} 0$ berbeda tidak nyata dengan $\mathrm{P} 4$ akan tetapi nyata $(\mathrm{P}<0,05)$ lebih tinggi dibanding $\mathrm{P} 1, \mathrm{P} 2$, dan P3.

Hal ini menunjukkan bahwa suplementasi 4,5g EDK/kg dan 0,5-1\% TK berdampak positif kecuali P4. Hal ini bertentangan dengan (Lawrie, 2003, dikutip oleh Prasetyo, 2013) yang menyatakan kadar protein yang tinggi menyebabkan meningkatnya kemampuan 
menahan air daging. Bertentangan juga dengan Wanniatie et al. (2012) pemberian tepung kunyit hingga $1 \%$ berpengaruh tidak nyata terhadap drip loss daging puyuh jantan. Drip loss P0 tidak berbeda dengan P4 hal ini belum diketahui apa penyebabnya. Hasil penelitian menunjukkan suplementasi EDK 4,5g/kg dan TK sampai $1 \%$ pada pakan berprotein rendah dapat menurunkan drip loss kecuali P4 (EDK 4,5g/kg dan TK 1\%).

Berdasarkan hasil penelitian dapat disimpulkan bahwa suplementasi EDK dan TK ke dalam pakan berprotein rendah meningkatkan warna karkas dan menurunkan drip loss, tetapi tidak mampu menghambat penurunan persentase berat karkas sebagai akibat pemberian pakan berprotein rendah.

\section{DAFTAR PUSTAKA}

Bregendahl, K. J., J. L. Sell and D. R. Zimmersnan. 2002. Effect of low protein diets on growth performance and body composition of broiler chicks. Poultry Sci., 81: 1156-1167.

Durrani, F. R., I. Mohammed, S. Asal, S. M. Shail, C. Naila. 2006. Effect of different levels of feed added turmeric (Curcuma longa) on the performance of broiler chicks. J. Agr. Biol. Sci. 1:9-11.

El-Hakim, Abd A. S., G. Cherian and M. N. Ali. 2009. Use of organic acid, herbs and their combination to improve the utilization of commercial low protein broiler diets. Int. $\mathbf{J}$, Poultry Sci., 8 (1) : 14-20.

Pelicia, V.C, J.R. Sartori, A.C. Stradiotti1, P.C Araujo1, M.K. Maruno1, G.V Polycarpo1, and A.C Pezzato. 2011. Glutamine, Glutamic Acid And Phytogenic Products As Alternative Additives In Broiler Feeds. Facultad de Medicina Veterinaria and Zootecnia, UNESP, Botucatu, SP, Brazil.

Pesti, G. M. 2009. Impact of dietary amino acid and crude protein level in broiler feeds on biological performance. J. appl. Poult. Res., 18: 477-486.

Prasetyo, U. M.C. Padaga. M.E. Sawitri. 2013. Kajian kualitas fisiko kimia daging sapi dipasar kota Malang. Jurnal Ilmu dan Teknologi Hasil Ternak. 8: 1-8.

Qotimah, S., U. Santoso dan E. Soetrisno. 2014. Pengaruh level protein dan suplementasi ekstrak daun katuk (Sauropus androgynus) terhadap kualitas karkas broiler. Jurnal Sain Peternakan Indonesia, 9: 130-136.

Rukmana, R. 2005. Kunyit. Kanisius.Yogyakarta.

Santoso, U. 2001. Effect of Sauropus androgynus extract on the 
carcass quality of broiler chicks. Buletin Ilmu Peternakan dan Perikanan 7: 22-28.

Santoso, U. 2002 ${ }^{\mathrm{a}}$. Effects of early feed restriction on the occurrence of compensatory growth, feed conversion efficiency, leg abnormality and mortality in unsexed broiler Chickens reared in cages. Asian-Aust. J. Anim. Sci. 15: 1319-1325.

Santoso, U. 2002 ${ }^{\mathrm{b}}$. Effects of early feed restriction on breast and leg meat composition and plasma lipid concentration in unsexed broiler chickens reared in cages. Asian-Aust. J. Anim. Sci. 2002. 15: 1475-1481.

Santoso, U., Suharyanto and E. Handayani. 2001. Effects of Sauropus androgynus (Katuk) leaf extract on growth, fat accumulation and fecal microorganisms in broiler chickens. Jurnal Ilmu Ternak dan Veteriner, 6: 220226.

Santoso, U., T. Suteky, Heyanto dan Sunarti. 2002. Pengaruh cara pemberian ekstrak daun katuk (Sauropus androgynus) terhadap penampilan kualitas karkas ayam pedaging. JITV. Vol. 7 no 3.

Santoso, U., J. Setianto and T. Suteky, 2005. Effects of Sauropus androgynus (katuk) extract on egg production and lipid metabolism in layers. AsianAustralasian J. Anim. Sci., 18: 364-369.

Santoso, U., Kususiyah dan Y. Fenita. 2013. Effect of Sauropus androgynus leaves extract on fat deposition in broiler fed low protein diets. J. Indonesian Trop. Anim. Agri., 38 (3) : 176-184.

Santoso. 2014. Katuk Tumbuhan Multi Khasiat. Bengkulu. Faperta Universitas Bengkulu.

Santoso, U., Y. Fenita, Kususiyah and I. G. N. G. Bidura. 2015. Effect of fermented Sauropus androgynus leaves on meat composition, amino acid and fatty acid compositions in broiler chickens. Pak. J. Nutr. 14:799-807.

Soeparno. 2009. Ilmu dan Teknologi Daging. Gadjah Mada University Press. Yogyakarta.

Swennen, Q., E. Decuypere and J. Buyse. 2007. Implications of dietary macronutrients for growth and metabilsm in broiler chicken. World's Poultry Sci. 63: 541556.

Wanniatie, V., D. Septinova, T. Kurtini, N. Purwaningsih. 2012. Pengaruh Pemberian Tepung Temulawak 
e-ISSN 2528-7109

p-ISSN 1978-3000

dan Kunyit terhadap Cooking Loss dan Driploss dan Uji Kebusukan Daging Puyuh Jantan. Artikel Ilmiah. Jurusan Peternakan Fakultas Pertanian Universitas Lampung.
Winarno, F. G. 1994. Pangan (Gizi, Teknologi dan Konsumen). Gramedia : Jakarta. 